\title{
Un colloque de l'Ecomusée du Creusot: "Les racines des paysages". Problématiques et acquis scientifiques
}

Gérard Chouquer et Patrice Notteghem

\section{(2) OpenEdition}

Journals

Édition électronique

URL : https://journals.openedition.org/tc/703

DOI : $10.4000 /$ tc. 703

ISSN : 1952-420X

Éditeur

Éditions de l'EHESS

Édition imprimée

Date de publication : 1 novembre 1992

ISSN : 0248-6016

Référence électronique

Gérard Chouquer et Patrice Notteghem, « Un colloque de l'Ecomusée du Creusot : "Les racines des paysages". Problématiques et acquis scientifiques », Techniques \& Culture [En ligne], 17-18| 1992, mis en ligne le 10 janvier 2006, consulté le 29 septembre 2022. URL : http://journals.openedition.org/tc/ 703 ; DOI : https://doi.org/10.4000/tc.703

Ce document a été généré automatiquement le 29 septembre 2022.

Tous droits réservés 
Un colloque de l'Ecomusée du Creusot: "Les racines des paysages". Problématiques et acquis scientifiques

Gérard Chouquer et Patrice Notteghem 